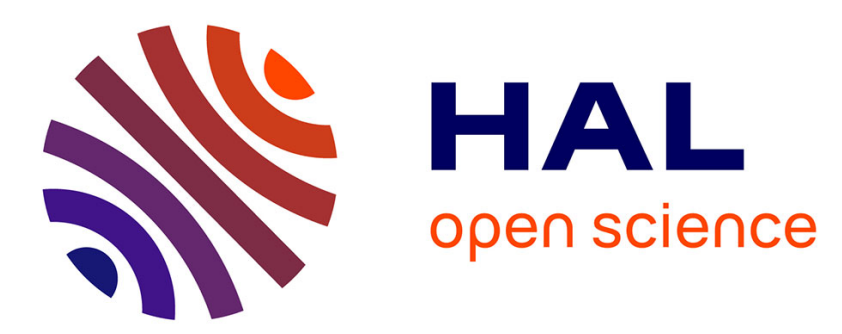

\title{
Estimate of Sahelian dust emissions in the intertropical discontinuity region of the West African Monsoon
}

Diana Bou Karam, Cyrille Flamant, Pierre Tulet, Jean-Pierre Chaboureau, Alain Dabas, Martin C. Todd

\section{- To cite this version:}

Diana Bou Karam, Cyrille Flamant, Pierre Tulet, Jean-Pierre Chaboureau, Alain Dabas, et al.. Estimate of Sahelian dust emissions in the intertropical discontinuity region of the West African Monsoon. Journal of Geophysical Research: Atmospheres, 2009, 114 (D13), pp.D13106. 10.1029/2008JD011444 . hal-00405156

\section{HAL Id: hal-00405156 https://hal.science/hal-00405156}

Submitted on 2 Mar 2016

HAL is a multi-disciplinary open access archive for the deposit and dissemination of scientific research documents, whether they are published or not. The documents may come from teaching and research institutions in France or abroad, or from public or private research centers.
L'archive ouverte pluridisciplinaire HAL, est destinée au dépôt et à la diffusion de documents scientifiques de niveau recherche, publiés ou non, émanant des établissements d'enseignement et de recherche français ou étrangers, des laboratoires publics ou privés. 


\title{
Estimate of Sahelian dust emissions in the intertropical discontinuity region of the West African Monsoon
}

\author{
Diana Bou Karam, ${ }^{1}$ Cyrille Flamant, ${ }^{1}$ Pierre Tulet, ${ }^{2}$ Jean-Pierre Chaboureau, ${ }^{3}$ \\ Alain Dabas, ${ }^{2}$ and Martin C. Todd ${ }^{4}$ \\ Received 10 November 2008; revised 10 May 2009; accepted 22 May 2009; published 11 July 2009.
}

[1] A three-dimensional mesoscale numerical simulation has been performed to investigate the dust emissions over the Sahel associated with strong near-surface winds in the region of the West African Inter Tropical Discontinuity (ITD) during the summer, when the ITD is located over Niger and Mali around $18^{\circ} \mathrm{N}$. The study focuses on the period from 2 to 12 July 2006, in the framework of the African Monsoon Multidisciplinary Analysis (AMMA) Special Observing Period 2a1. The comparison with observations suggests that the model can be used reliably to analyze and quantify the dust emissions associated with the strong near-surface winds blowing over the Sahelian dust sources during the period of interest. The daily mean values of dust load related to the strong winds on both side of the ITD, as estimated from the simulation within the model domain $\left(2^{\circ} \mathrm{W}-16^{\circ} \mathrm{E}, 12-28^{\circ} \mathrm{N}\right)$, are in excess of $2 \mathrm{Tg}$ on some of the days of the $2-12$ July 2006 period. In the present case, the dust load associated with the strong winds south of the ITD accounts for between one third and two thirds of the total load mobilized in the ITD region over the entire domain on a given day. It is simulated to range between 0.5 and $0.8 \mathrm{Tg}$ on average. This study suggests that emissions driven by strong surface winds occurring on both sides of the ITD while lying across the Sahel may contribute significantly to the total dust load over West and North Africa observed annually.

Citation: Bou Karam, D., C. Flamant, P. Tulet, J.-P. Chaboureau, A. Dabas, and M. C. Todd (2009), Estimate of Sahelian dust emissions in the intertropical discontinuity region of the West African Monsoon, J. Geophys. Res., 114, D13106, doi:10.1029/2008JD011444.

\section{Introduction}

[2] North Africa is the world's largest source of mineral dust. Satellite observations consistently indicate that dust aerosol plumes are the most widespread, persistent and dense found on Earth [e.g., Prospero et al., 2002]. Dust emitted from desert regions and transported in the atmosphere has been recognized to be an important component of the Earth's climate system because of its influence on the Earth's radiation budget [e.g., Haywood et al., 2003]. In many region, dust is the biggest contribution to atmospheric optical thickness [Tegen et al., 1997], while still being one of the greatest source of uncertainty in projection of future climate change [Ramaswamy et al., 2001]. This is particularly true over North and West Africa where dust emission

\footnotetext{
${ }^{1}$ Laboratoire ATmospheres Milieux Observations Spatiales/Institut Pierre et Simon Laplace, Université Pierre et Marie Curie and CNRS, Paris, France.

${ }^{2}$ Centre National de Recherche Meteorologique/Groupe d'etude de l'Atmosphere MEteorologique, Météo-France and CNRS, Toulouse, France.

${ }^{3}$ Laboratoire d'Aérologie, Université de Toulouse and CNRS, Toulouse, France.

${ }^{4}$ Department of Geography, University College London, London, UK.

Copyright 2009 by the American Geophysical Union. 0148-0227/09/2008JD011444
}

and transport has been shown to be highly variable in time and space with an annual peak during summer [e.g., Prospero et al., 2002; Engelstaedter and Washington, 2007]. Importantly, there is now evidence that dust emission are associated with meteorological features occurring on a variety of scales from localized features like dust devils to mesoscale and synoptic phenomena.

[3] Because of the important role that mineral dust may play in the context of climate change and weather forecasts [Forster et al., 2007], it is important that the variety of dust lifting mechanisms be realistically represented in atmospheric models. Using a regional dust model, Schepanski et al. [2009] have demonstrated that the activation of the West African dust sources during the monsoon season, when the annual peak of dust emissions over West Africa is observed [e.g., Engelstaedter and Washington, 2007], is underestimated by the model. Hence accurate simulation of dust generating mechanisms active during the monsoon season, is particularly important for determining the overall contribution of a given source region to the aerosol load over North and West Africa. To date, the monitoring of dust emissions in Africa mostly relies on space-borne observations [e.g., Prospero et al., 2002; Schepanski et al., 2007] and is unambiguous only in the case of specific isolated outbreak events. During most of the year, the large number of simultaneously activated sources as well as the impor- 
tance of large scale transport, only allows the dust load to be monitored from space. Recent research has identified numerous mechanisms associated with dust emission over North Africa. Dust storms have been documented to be associated with high near-surface wind speeds resulting from the downward mixing of momentum from the nocturnal low-level jets (LLJs). Such outbreaks occur in response to the Saharan heat low dynamics [e.g., Knippertz, 2008] or are connected to LLJs generated in the lee of complex terrain as is the case in the Bodélé region of Northern Chad [e.g., Washington and Todd, 2005; Todd et al., 2008a]. Occasional strong dust outbreaks have been documented to be associated with the penetration of upper level troughs to low latitudes [e.g., Jankowiak and Tanré, 1992], or to density currents caused by strong evaporational cooling along precipitating cloud bands over the northern Sahara [Knippertz and Fink, 2006] and along the Sahara side of the Atlas Mountain chain in southern Morocco [Knippertz et al., 2007]. Over the Sahel, density currents associated with mesoscale convective systems (MCSs), offer the most efficient mechanism for dust emission and injection to altitudes favorable for long-range transport, particularly at the beginning of the monsoon season, before the growing vegetation rapidly inhibits local dust emission [e.g., Sterk, 2002; Flamant et al., 2007] and when greater energy is available to the downdraughts from the storms [Marsham et al., 2008]. More recently, Bou Karam et al. [2008] have identified a new mechanism for dust emission over the Sahel during the summer, in which highly turbulent winds at the leading edge of the monsoon nocturnal flow in the Inter Tropical Discontinuity (ITD) region generate dust uplifting. Using in situ measurements, Marsham et al. [2008] have described the thermodynamic characteristics of the dusty layer at the leading edge of the monsoon flow over the Sahel and have shown higher dust concentrations in the monsoon layer compared to those observed in the harmattan layer.

[4] Because dust sources are widespread over the Sahel and presumably active on many days when the monsoon leading edge is located in this region during the summer, dust emissions associated with the dust lifting mechanism detailed by Bou Karam et al. [2008] may contribute significantly to the total dust production in West Africa. The objective of this study is two-fold: (1) to evaluate the ability of a mesoscale atmospheric model (Meso-NH) to represent the dust lifting mechanism detailed by Bou Karam et al. [2008] and (2) to estimate the dust load associated with this mechanism during the period from 2 to 12 July 2006.

[5] The remainder of the paper is organized as follows. Section 2 details the mesoscale model and the modeling strategy as well as the observations used in this study. In section 3, the evaluation of the model from a dynamics point of view is discussed. Section 4 details the simulated dust emission fields. The estimate of dust load in the ITD region is discussed in section 5 . The paper concludes in section 6 .

\section{Data Sources}

\subsection{Mesoscale Simulation}

\subsubsection{Model Description}

[6] The simulation has been carried out using Meso-NH [Lafore et al., 1998], a nonhydrostatic mesoscale atmo- spheric model with an online dust emission and transport module. Meso-NH includes parameterizations of various processes including cloud microphysics [Cohard and Pinty, 2000], turbulence [Bougeault and Lacarrére, 1989], deep convection [Bechtold et al., 2001], lightning processes [Barthe et al., 2005], gaseous chemistry [Suhre et al., 1998], chemical aerosol [Tulet et al., 2005] and dust aerosol [Grini et al., 2006]. The deep convection, cloud microphysics, lightning, gaseous chemistry and chemical aerosol packages come as options in the model and are not activated in the present simulation.

[7] Meso-NH is coupled to an externalized surface model which handles heat and water vapor fluxes between the lowlevel atmosphere and four types of surface: vegetation, towns, oceans and lakes [Masson et al., 2003]. Natural land surfaces are described by interactions treated in the Soil Biosphere and Atmosphere model (ISBA) [Noilhan and Mahfouf, 1996].

[8] The dust emission scheme is the Dust Entrainment And Deposition (DEAD) model [Zender et al., 2003], implemented as a component of Meso-NH [Grini et al., 2006], that calculates dust flux from wind friction velocity. DEAD includes entrainment thresholds for saltation, moisture inhibition and saltation feedback. The ORILAM model [Tulet et al., 2005] simulates transport and loss processes by following the evolution of two moments of three lognormal modes defined by Alfaro and Gomes [2001]. Dust advection and diffusion are quantified by the transport processes and methods used in Meso-NH which include mixing within the planetary boundary layer, shallow convective transport and advection by winds. Meso-NH uses the radiative scheme of the European Centre for Medium-range Weather Forecasts (ECMWF), which computes shortwave and longwave radiative fluxes. Shortwave radiative fluxes are computed for 6 wavelengths using the extinction coefficients, asymmetry factors and single scattering albedo provided by lookup tables.

[9] The decision to use Meso-NH was based on the fact that the mesoscale dynamics is what drives the dust mobilization and that it needs to be well reproduced in the simulation in order to assess a reliable model-based estimate of the dust emission in the region. The performances of Meso-NH, especially in terms of dynamics and thermodynamics, are well established and its ability to simulate dust emission and transport over West Africa has been highlighted in several recent studies [e.g., Grini et al., 2006; Chaboureau et al., 2007; Tulet et al., 2008; Crumeyrolle et al., 2008; Todd et al., 2008b; Bou Karam et al., 2009]. The choice of this model is what limits the length of the simulation, as Meso-NH was not designed to produce long-term simulations, but rather case studies of at most 7 to 10 days (which is already quite long for such a model).

\subsubsection{Modeling Strategy}

[10] There are 3 major contributions to the observed AOD values anywhere over Sahel: (1) the dust mobilized as the result of strong near-surface winds on both sides of the ITD, (2) the dust mobilized at the leading edge of cold pools issued from mesoscale convective systems south of the ITD, and (3) the dust that is not mobilized locally but advected over the Sahel from remote Saharan sources.

[11] Because, the overall objective is to determine the dust load associated with the emission occurring at the 


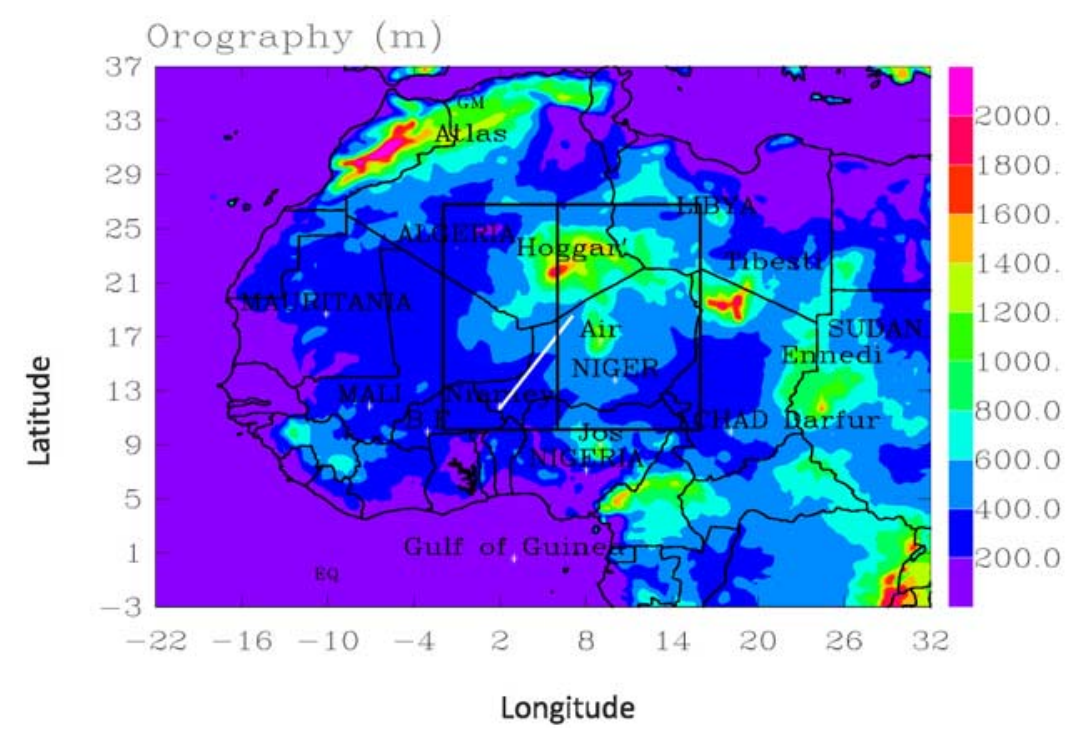

Figure 1. Map of Africa showing the orography (m) over the continent. The domain of the Meso-NH simulation is shown by the black box. The white solid line shows the aircraft flight track on 7 July 2006. The black solid line represents the location of the cross section used for the calculations in Figure 2.

leading edge of the monsoon flow and subsequently transported south within or just above the monsoon layer, the simulation was designed only to reproduce dust mobilization associated with item (1) above.

[12] Deep convection is not activated in the simulation, and hence, dust mobilization associated with item (2) is not accounted for. Furthermore, the initial and lateral boundary conditions do not include information on the distribution of dust aerosol over the whole continent, meaning that the model does not account for dust mobilized outside of the simulation domain.

\subsubsection{Simulation Description}

[13] In this study a 10-day simulation (2-12 July 2006) was performed. The study area covering Niger, Eastern Mali and southern Algeria forms a domain of $1000 \mathrm{~km} \times$ $1000 \mathrm{~km}$ (centered on $20^{\circ} \mathrm{N} / 7^{\circ} \mathrm{E}$ ) with a horizontal mesh size of $20 \mathrm{~km}$ (see Figure 1). In the vertical, 62 levels were used with 35 of them within the planetary boundary layer (i.e., below $2 \mathrm{~km}$ ). The lowermost level is at $30 \mathrm{~m}$ above the ground, while the highest level is at $28 \mathrm{~km}$ above the ground. Initial and lateral boundary conditions were taken from the ECMWF analyses. In order to keep the simulation close to the analyzed meteorological conditions, the boundary conditions of the simulations were nudged toward the ECMWF analyses with a 6-hour timescale. ECMWF temperature, humidity and wind fields are nudged throughout the depth of the atmospheric column.

[14] The domain of the simulation encompasses the prominent dust sources over Mali, Algeria and Niger that are generally activated in the summer season. The region to the south and west of the Hoggar and to the west and east of the Aïr Mountains is characterized by a huge system of paleo and ephemeral rivers and streams that drain the Hoggar and Aïr massifs, thereby producing a complex array of dust sources consisting of fluvial deposits. There also exist similar dust sources in northern Niger close to the Libya and Chad borders, i.e., ephemeral rivers and streams that drain the Tibesti and the Djado plateau (between the Tibesti and Hoggar Mountains). A recent study by Schepanski et al. [2007], based on the Meteosat Second Generation (MSG) Spinning Enhanced Visible and Infrared Imager (SEVIRI) dust index, has shown that the sources around the Air Mountains were the most active during the month of July 2006, together with the sources over northern Mali, close to the border with Algeria [see Schepanski et al., 2007, Figure 2a]. The sources over northern Niger (south of the Djado plateau) were also activated, but were not prominent dust suppliers.

\subsection{Observations}

\subsubsection{Airborne Lidar Observations}

[15] The dust uplifting mechanisms associated with the strong near-surface winds at the leading edge of the monsoon flow in the ITD region have been investigated by means of airborne lidars measurements acquired from two platforms in the morning of 7 July 2006 [Bou Karam et al., 2008], during the African Monsoon Multidisciplinary Analysis (AMMA [Redelsperger et al., 2006]) Special Observing Period denoted "2a1". The Service des Avions Français Instrumentés pour la Recherche en Environnement (SAFIRE) Falcon 20 (hereafter F/F20) was equipped with the airborne differential absorption lidar LEANDRE 2 [Bruneau et al., 2001; Flamant et al., 2007], while the Deutsches Zentrum für Luft- und Raumfahrt (DLR) Falcon 20 (hereafter D/F20) was equipped with the airborne Wind Infrared Doppler lidar (WIND [Werner et al., 2001; Reitebuch et al., 2001]). The measurements were made over northern Niger, southwest of the Hoggar and the Aïr Mountains (Figure 1). Both aircraft flew at approximately $8 \mathrm{~km}$ above mean sea level (msl) from Niamey $\left(2.16^{\circ} \mathrm{E} /\right.$ $\left.13.5^{\circ} \mathrm{N}\right)$ to a point close to the Algerian border located at $7^{\circ} \mathrm{E} / 20^{\circ} \mathrm{N}$. The mission was performed in the early morning between 0600 UTC and 0900 UTC (between 0700 and 1000 LT, i.e., shortly after sunrise which was around 0545 LT 

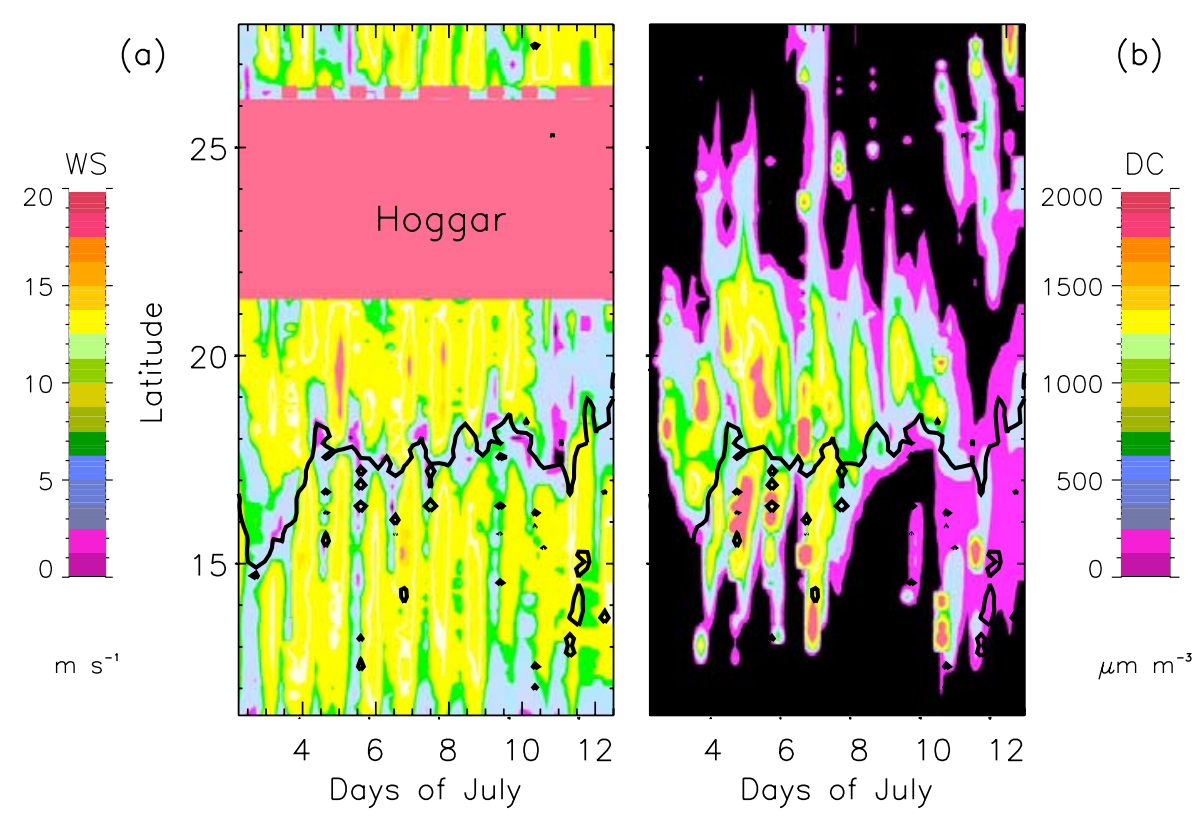

Figure 2. Hovmoeller diagram at $6^{\circ} \mathrm{E}$ over $12-28 \mathrm{~N}$ of (a) wind speed at $925 \mathrm{hPa}$ and (b) dust concentration at $30 \mathrm{~m}$ agl simulated with Meso-NH. The black line represents the ITD.

in the region of operations), when the monsoon flow is typically strong and the ITD is well defined. WIND-derived vertical profiles of the horizontal wind vector are determined by a conical scan using the Velocity Azimuth Display technique. The vertical and horizontal resolutions of the wind field are $250 \mathrm{~m}$ and about $4 \mathrm{~km}$, respectively. LEANDREderived atmospheric reflectivity (at $730 \mathrm{~nm}$ ) is mostly sensitive to aerosols with radii ranging from 0.1 to $5 \mu \mathrm{m}$, and hence to dust aerosols [e.g., Flamant et al., 2007]. Reflectivity associated with desert dust is generally not expected to be sensitive to relative humidity fluctuations, especially close to the emission sources. Hence reflectivity may be considered as a good proxy for aerosol concentration (i.e., it provides reliable qualitative information on the location of the dust layers, not quantitative information). The vertical and horizontal resolutions of the reflectivity field are $15 \mathrm{~m}$ and about $1.5 \mathrm{~km}$, respectively. In the present study, lidar data are used mainly for model validation purposes.

\subsubsection{Ground-Based Measurements}

[16] Observed surface thermodynamics measurements were also used for model validation purposes over the entire period from 2 to 12 July 2006. Surface wind (10 m above ground level, agl), temperature and humidity ( $2 \mathrm{~m} \mathrm{agl})$ acquired in Niamey, Niger, were obtained from meteorological station instruments deployed in the framework of the ARM Mobile Facility detachment [e.g., Slingo et al., 2008], while aerosol optical depth (AOD) data were obtained from the Sun photometer instrument deployed at Banizoumbou, Niger, (20 km away from Niamey) under the AERONET project (level 2 cloud-screened product data were used here). The ARM data used here was available at a $1 \mathrm{~min}$. sampling rate. The sampling rate associated with the Sun photometer "direct sun" measurements is on the order of a few minutes. However, the temporal resolution of the AOD retrievals is quite variable due to the screening applied to the data in the presence of clouds.

\subsubsection{Space-Borne Observations}

[17] The horizontal distribution of dust is described using SEVIRI images produced from a combination of three infrared channels, namely channel $10(12 \mu \mathrm{m})$, channel 9 $(10.8 \mu \mathrm{m})$ and channel $7(8.7 \mu \mathrm{m})$. False-color images (available on http://radagast.nerc-essc.ac.uk/SEVIRI Dust.shtml) are created using an algorithm developed by EUMETSAT which colors red the difference between the 12.0 and $10.8 \mu \mathrm{m}$ channels, green the difference between the 10.8 and $8.7 \mu \mathrm{m}$ channels and blue the $10.8 \mu \mathrm{m}$ channel [e.g., Schepanski et al., 2007]. On these composite images, dust appears pink or magenta.

[18] Finally, daily $1^{\circ} \times 1^{\circ}$ resolution AOD fields obtained from the Moderate Resolution Imaging Spectroradiometer (MODIS)/AQUA Deep Blue Collection 005 over desertic surfaces (MOD08 product) were used to compute dust mass loads associated with the emissions in the ITD region, using the relationship proposed by Koren et al. [2006], and updated by Todd et al. [2007].

\section{Low-Level Dynamics and Associated Dust Emissions During the Study Period}

[19] During the 2-12 July 2006 period, prevailing meteorological conditions over West Africa are investigated using the Meso-NH simulation. Figure 2 shows a Hovmoeller diagram at $6^{\circ} \mathrm{E}$ over $12-28^{\circ} \mathrm{N}$ for wind speed at $925 \mathrm{hPa}$ (Figure 2a) and dust concentration at $30 \mathrm{~m} \mathrm{agl}$ (Figure 2b). During 2-12 July 2006, Niger (and Mali, not shown) was under the influence of strong opposing winds (in excess of $16 \mathrm{~m} \mathrm{~s}^{-1}$ at $925 \mathrm{hPa}$ ) separated by an area of weak winds $\left(\sim 2 \mathrm{~m} \mathrm{~s}^{-1}\right)$ close to $17^{\circ} \mathrm{N}$ corresponding to the ITD.

[20] Buckle [1996] defines the ITD using a $14^{\circ} \mathrm{C}$ dewpoint temperature criterion, with air to the north (south) of the ITD being characterized by dew-point temperatures less than (in excess of) $14^{\circ} \mathrm{C}$ and northerly to easterly (southerly to westerly) winds. The ITD is generally best defined during 
(a)

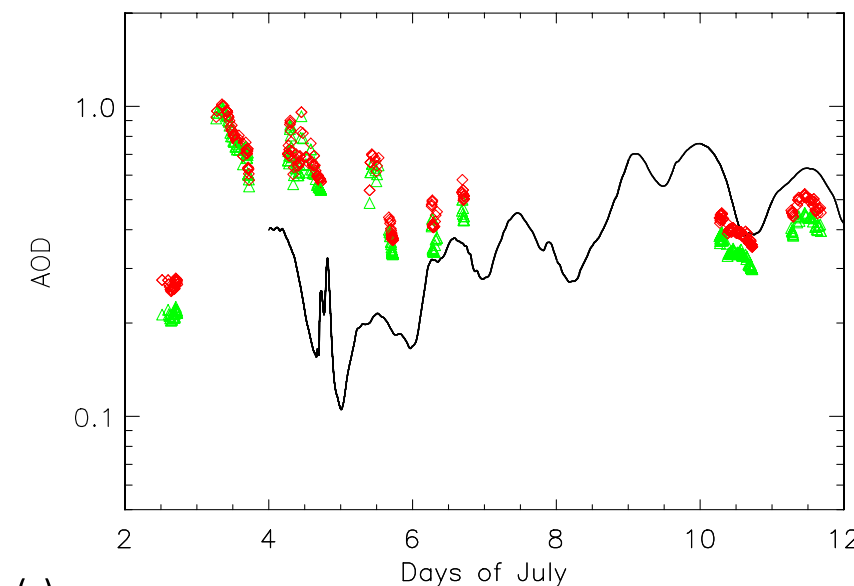

(c)

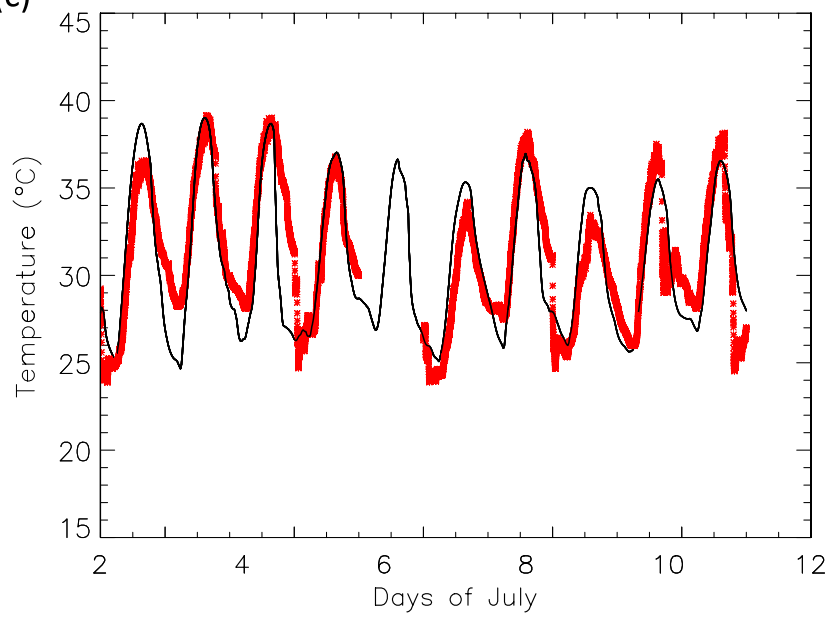

(b)

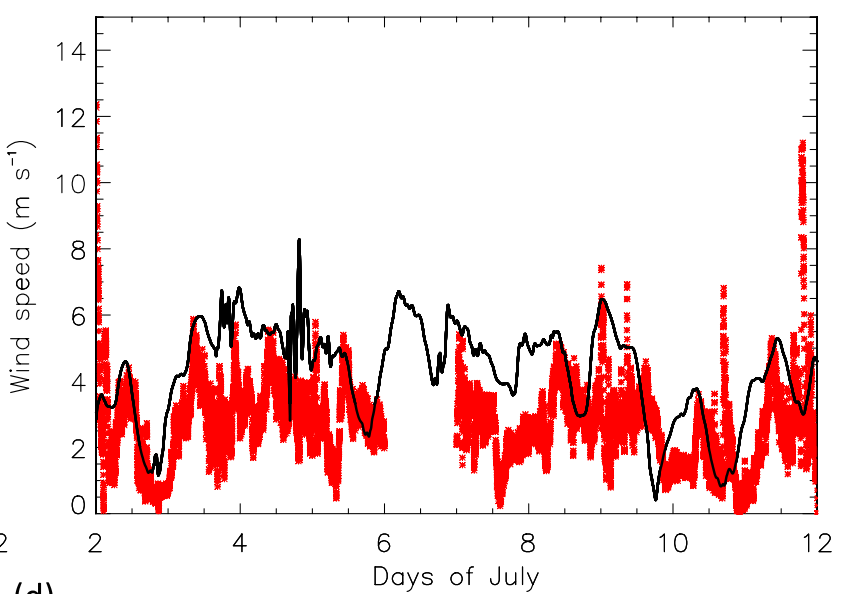

(d)

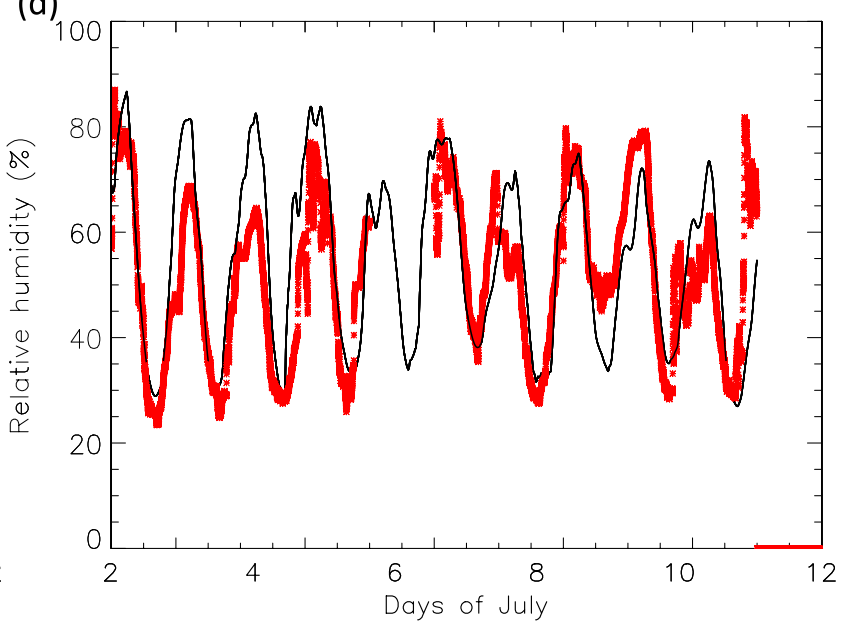

Figure 3. (a) Sun photometer-derived AOD measured in Banizoumbou, Niger, at $675 \mathrm{~nm}$ (green triangles) and at $440 \mathrm{~nm}$ (red diamonds) and simulated at $550 \mathrm{~nm}$ with Meso-NH between 2 and 12 July 2006. Comparison of Meso-NH derived (solid line) and observed (red dots) data at (b) 10-m wind speed, (c) 2-m temperature, and (d) 2-m relative humidity in Niamey, Niger, between 2 and 12 July 2006.

the night, when in the absence of thermally driven turbulence in the PBL, the monsoon flow progresses northward, thereby leading to the existence of a sharp density gradient across the monsoon-harmattan interface. The density gradient results from the difference in temperature and humidity between the monsoon flow (cold and wet) and the harmattan flow (dry and hot [e.g., Hamilton and Archibald, 1945]). This is why the position of the ITD is generally presented at 0600 UTC on charts. In the daytime, the turbulence in the PBL tends to mix the opposing flows, thereby decreasing the density gradient across the monsoon-harmattan interface, and making it appear that the ITD is retreating south. In the following, we have used the $14^{\circ} \mathrm{C}$ dew-point temperature criterion to determine the position of the ITD in the simulation, using the dew-point temperature computed on the lowest model level (i.e., $30 \mathrm{~m} \mathrm{agl}$ ).

[21] To the north of the ITD, where the northeasterly flow is modulated by the presence of orography, the strong winds are connected to the formation of nocturnal LLJs (above the nocturnal inversion [e.g., Thorpe and Guymer, 1977]). South of the ITD, they correspond to the strong southwesterly monsoon flow (Figure 2). The winds on both side of the ITD and the ITD itself manifested a marked diurnal cycle as illustrated in Figure 2 with the strongest winds during the night and shortly before sunrise. The position of the ITD over Niger and Mali was seen to evolve northward between 2 and 12 July, from $15^{\circ} \mathrm{N}$ to $19^{\circ} \mathrm{N}$ where it reaches the foothills of the Aïr Mountains.

[22] The LLJs seen to the north of the ITD were responsible for large dust uplifts simulated in the morning hours after sunrise during the 2-12 July period (Figure 2 right panel). These emissions to the north of the ITD are related to surface wind speed maxima that occur in the hours after sunrise. The phase shift in the diurnal cycle of the LLJ and surface winds is associated with the downward transfer of momentum from the nocturnal LLJ to the surface due to turbulent mixing after solar heating commences each day. This has been well established in the Bodélé region for instance [e.g., Todd et al., 2007].

[23] To the south of the ITD, dust emissions seem to occur preferably during night and the early morning hours (before sunrise) and are in phase with the simulated winds maxima (Figure 2). This is related to the mechanism identified by Bou Karam et al. [2008] in which highly turbulent winds along the leading edge of the monsoon flow lead to dust uplifts over Sahara-Sahel. The dust emissions 

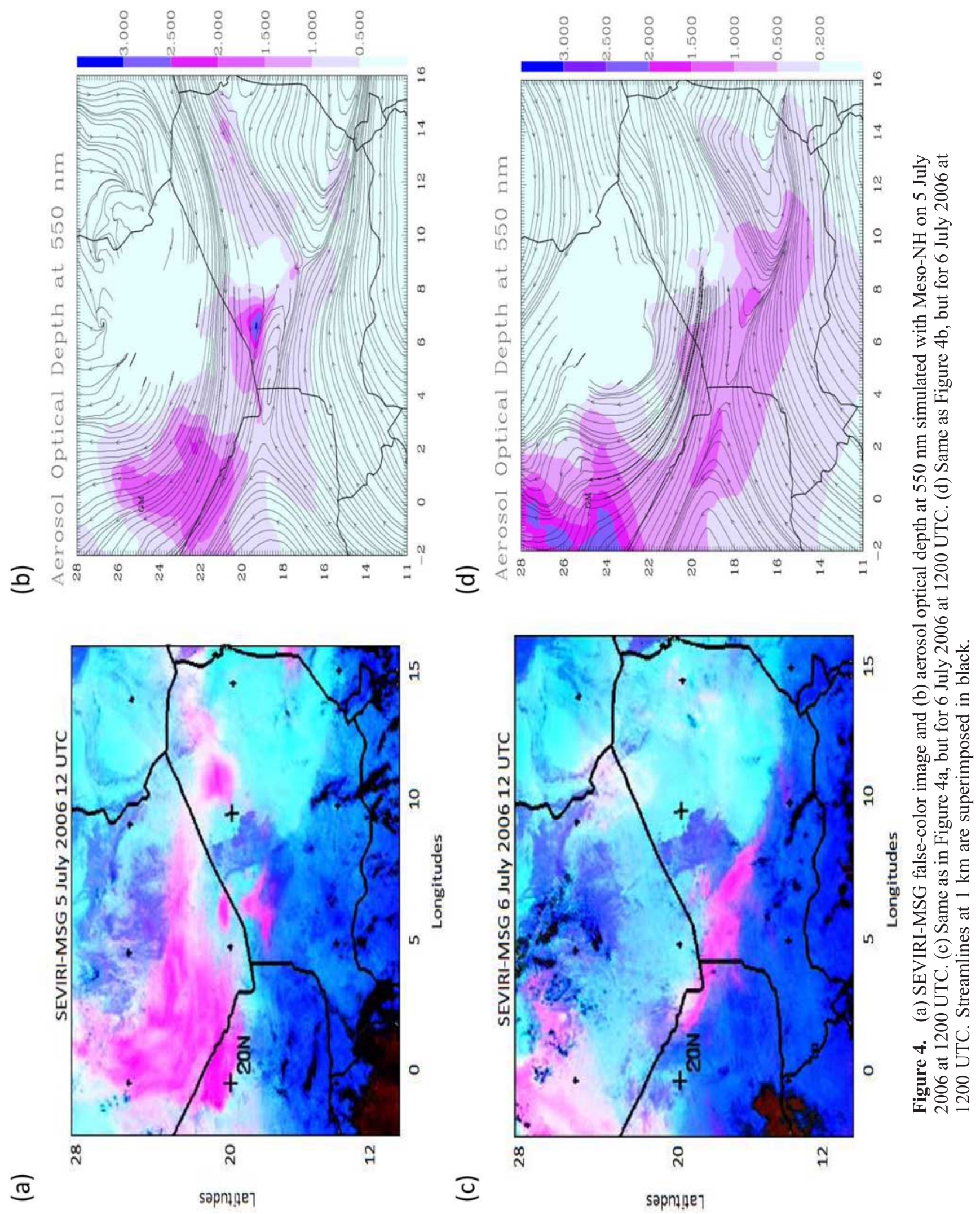

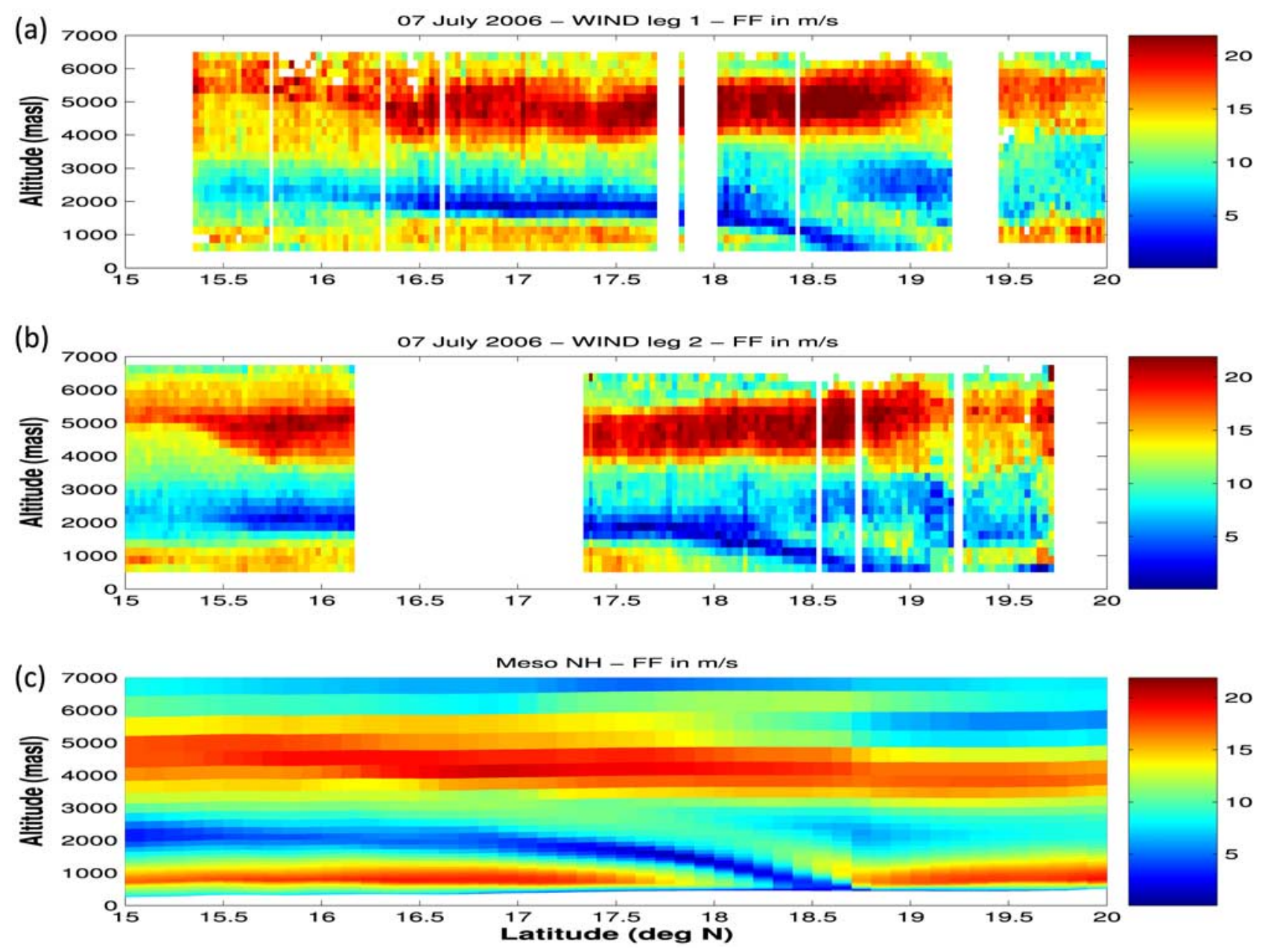

Figure 5. Along aircraft track cross section of wind speed derived from WIND on 7 July 2006 between (a) 0616 and 0718 UTC and (b) 0719 and 0827 UTC and (c) from simulation at 0600 UTC. The $x$ axis represents latitudes, and the $y$ axis represents altitudes $(\mathrm{m})$.

associated with this mechanism were simulated in the early morning hours, when the nocturnal monsoon flow was still behaving as an intruding density current, advancing into the harmattan flow (Figure 2).

\section{Model Validation}

[24] Because the mesoscale dynamics is what drives the dust mobilization, the model needs to accurately reproduce the dynamics and thermodynamics fields (especially near the surface), in order to be able to get a reliable model-based estimate of the dust emission in the region of the ITD. The scope of this section is to verify the overall good behavior of the model in terms of dynamics and thermodynamics by comparing it to available observations.

\subsection{Ground Based Measurements in Niamey and Banizoumbou}

[25] At the location of Banizoumbou in the zone of monsoon southwesterly winds, the simulated AODs are found to be underestimated by up to a factor of 4 with respect to the Sun photometer-derived AODs for the period from 4 to 8 July, while being slightly overestimated by up to a factor of 1.4 on 10 and 11 July (Figure 3a). Model-derived
AODs on 2 and 3 July were discarded, essentially because of aerosol-related spin-up time issues. This is related to the fact that the initial conditions issued from ECMWF do not include information on the dust aerosol distribution. The model needs about two days to develop a realistic dust concentration field through emissions and transport (i.e., from 4 July on) as assessed from comparison with SEVERI false-color images.

[26] Observed $10 \mathrm{~m}$ winds at Niamey exhibit a diurnal cycle (Figure 3b), as expected in this region [Parker et al., 2005]. The simulated wind speeds are seen to be overestimated by up to a factor of 1.25 , while the diurnal evolution of the wind speed is found in fair agreement with the observations (Figure 3b). The simulated 2-m temperature and relative humidity are in reasonable agreement with the observations (Figures 3c and 3d). Linear Pearson correlation coefficient values of 0.85 and 0.86 were obtained between the temperature and relative humidity extracted from the lowest level of the simulation and their observed counterparts. Furthermore, the related biases were found to be equal to $0.3^{\circ} \mathrm{C}$ and $5 \%$ for temperature and relative humidity, respectively (the largest values being obtained for the observations). On the other hand, the correlation between 


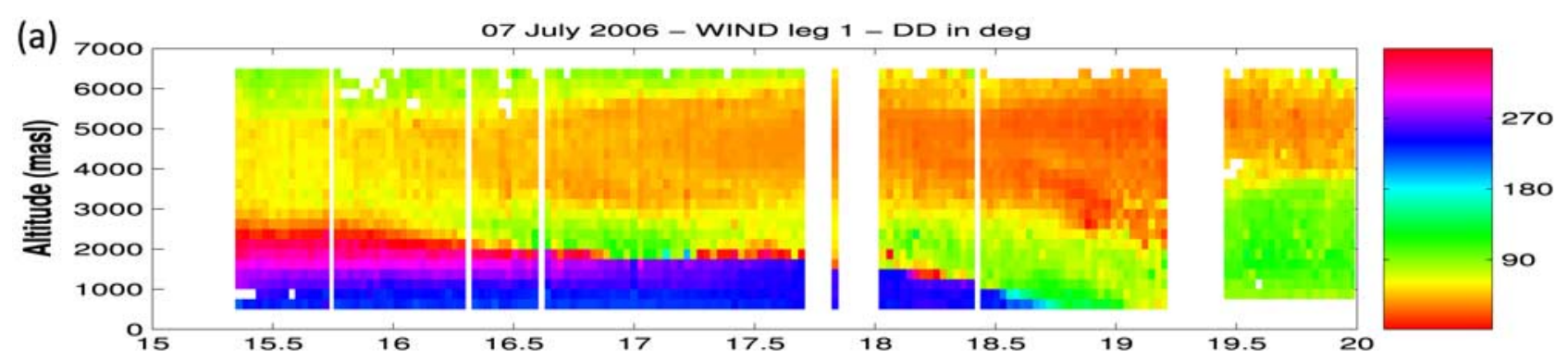

(b)

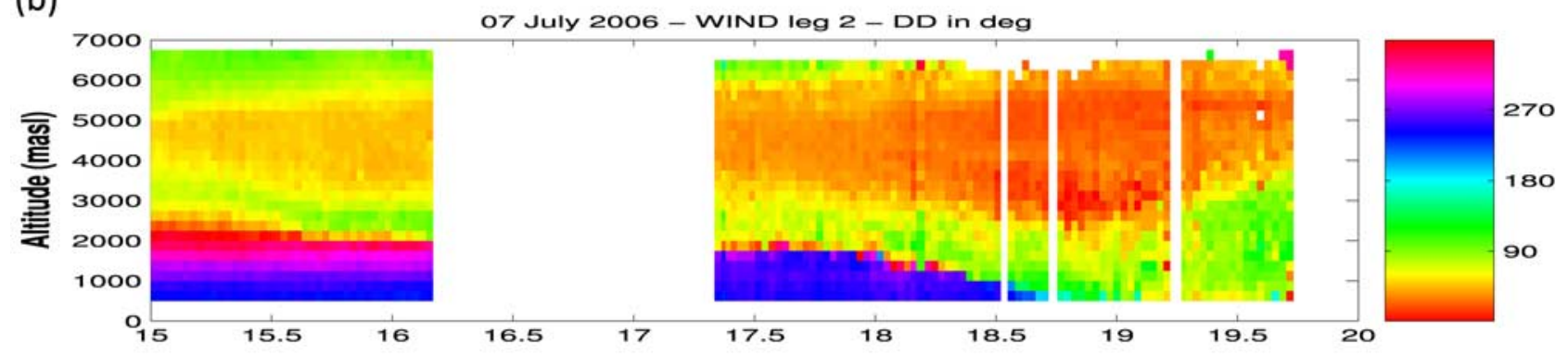

(c)

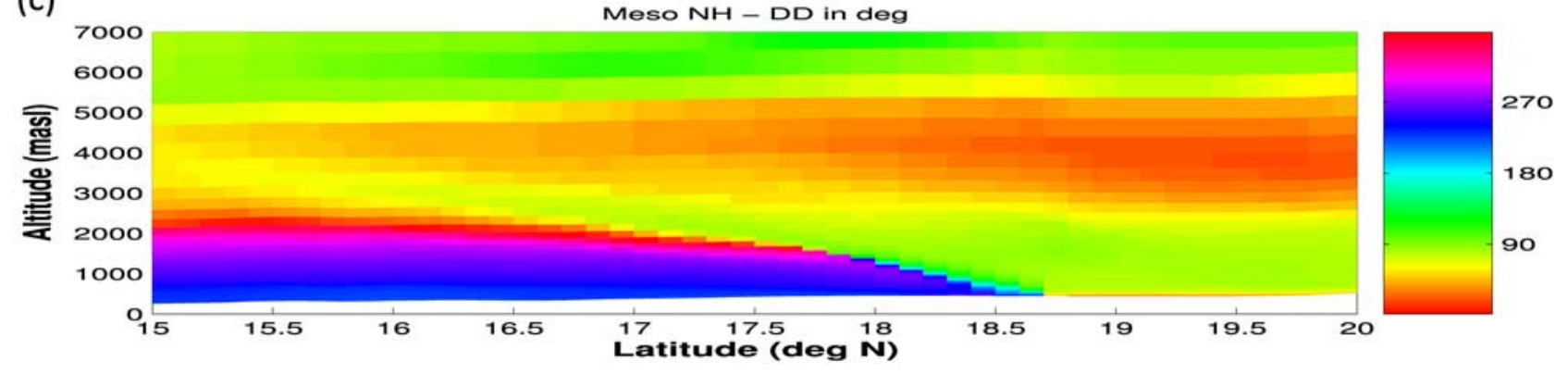

Figure 6. Same as Figure 5, but for wind direction.

the observed and simulated wind speeds was only of 0.42 , with a bias of $-1.5 \mathrm{~m} \mathrm{~s}^{-1}$.

\subsection{Horizontal Dust Distribution on 5 and 6 July 2006}

[27] The SEVIRI false-color image on 5 July 2006 at 1200 UTC shows a large dust cloud covering the Hoggar southwest foothills. Large amounts of dust were observed also (1) west of the Hoggar Mountains over Algeria, (2) west of the Air Mountains probably associated with cyclonic activity in the ITD region as discussed by Bou Karam et al. [2009] (see the closed circulation seen in the streamlines in Figure $4 \mathrm{~b}$ near $4^{\circ} \mathrm{E}, 18.5^{\circ} \mathrm{N}$ ) and (3) over northern Niger (Figure 4a). This distribution of dust over the study domain was well reproduced by Meso-NH (Figure 4b). Modelled AOD values (at $550 \mathrm{~nm}$ ) in excess of 2 were associated with the dust load present over southern Algeria. AODs as large as 3 were modelled to be associated with the dust seen over Niger. A similar consistency between the model and SEVIRI observations was found on 6 July 2006 at 1200 UTC. On that day, the ITD was visible on the SEVIRI image as a linear dust feature along it resulting from the westward zonal advection of the vertically mixed dust (Figure 4c). The location of this structure was well captured by the model (Figure 4d).

\subsection{Vertical Distribution of Dust in the ITD Region}

[28] To assess whether the model can reproduce the dust lifting observed to occur near the leading edge of the nocturnal monsoon flow, we first compare the vertical structure of the simulated wind fields with the WINDderived observations along the flight track from Niamey and back acquired on 7 July 2006 (see Figure 1). The structure and the intensity of the main dynamical features present over Niger on that day are well captured by the model (Figures 5 and 6). The near-surface wind reversal associated with the ITD observed to be around $18.7^{\circ} \mathrm{N}$ along both transect (Figures $5 \mathrm{a}$ and $5 \mathrm{~b}$ ) is simulated in the right position (Figure $5 \mathrm{c}$ ). The structure of the monsoonharmattan interface (not just the ITD) standing out clearly in the WIND data as the region of very light winds separating the two opposing flows (Figures $5 \mathrm{a}$ and $5 \mathrm{~b}$ ) is also well represented in the model. The depth and direction of the monsoon flow in the simulation is quite realistic (Figure 6). The African easterly jet is clearly seen in the WIND data, extending throughout the entire aircraft leg, with the largest wind speeds between 5 and $6 \mathrm{~km} \mathrm{msl}$ (Figure 5). It is realistically represented in the simulation even though the maximum wind speeds as well as the depth of the AEJ layer are greater in the observations than in the model (Figures $5 \mathrm{c}$ and $6 \mathrm{c}$ ). North of the ITD, WIND data evidence the 
Table 1. Bias and Standard Deviation of WIND Observations Minus Meso-NH Simulation for Wind Speed and Direction ${ }^{\mathrm{a}}$

\begin{tabular}{|c|c|c|c|c|c|}
\hline & \multirow[b]{2}{*}{ Altitude Range ( $\mathrm{km} \mathrm{msl})$} & \multicolumn{2}{|c|}{ Wind Speed } & \multicolumn{2}{|c|}{ Wind Direction } \\
\hline & & $\operatorname{Bias}\left(\mathrm{m} \mathrm{s}^{-1}\right)$ & Standard Deviation $\left(\mathrm{m} \mathrm{s}^{-1}\right)$ & $\operatorname{Bias}\left({ }^{\circ}\right)$ & Standard Deviation $\left({ }^{\circ}\right)$ \\
\hline South of $18.5^{\circ} \mathrm{N}$ & $\begin{array}{l}0.62-2 \\
2-4 \\
4-6\end{array}$ & $\begin{array}{l}0.24 \\
0.32 \\
1.57\end{array}$ & $\begin{array}{l}2.95 \\
2.57 \\
3.63\end{array}$ & $\begin{array}{l}-8.3 \\
-5.7 \\
-3.6\end{array}$ & $\begin{array}{l}45 \\
9.5 \\
8.2\end{array}$ \\
\hline North of $18.5^{\circ} \mathrm{N}$ & $\begin{array}{l}0.62-2 \\
2-4 \\
4-6\end{array}$ & $\begin{array}{l}-0.90 \\
-1.92 \\
4.05\end{array}$ & $\begin{array}{l}2.96 \\
2.22 \\
4.71\end{array}$ & $\begin{array}{l}11.8 \\
15.6 \\
-2.3\end{array}$ & $\begin{array}{l}14 \\
32 \\
16\end{array}$ \\
\hline
\end{tabular}

${ }^{a}$ WIND observations were acquired on 7 July 2006 between 0616 and 0718 UTC. The modeled wind speed and directions are extracted from the simulation at 0600 UTC.

existence of a thin near-surface layer of strong easterly winds $\left(12-14 \mathrm{~m} \mathrm{~s}^{-1}\right)$, separated from the northeasterly midlevel jet $\left(16 \mathrm{~m} \mathrm{~s}^{-1}\right.$ or more) by a layer of weaker winds $\left(8 \mathrm{~m} \mathrm{~s}^{-1}\right)$ as seen in Figures $5 \mathrm{a}$ and $5 \mathrm{~b}$. This feature, a lowlevel jet induced by channeling in the lee of the constriction between the Air and the Hoggar, is well represented in the model. This low-level jet has important implications in terms of the dust lifting to the north of the ITD as discussed earlier.

[29] More detailed comparisons between the WINDderived and Meso-NH-derived wind speed and direction along the leg were also done to assess the performance of the model (Table 1). We have computed biases and standard deviation associated with these fields in 3 ranges of altitudes as well as north and south of the ITD. The 3 altitude ranges correspond to layers in which (1) the monsoon and harmattan winds $(0.62-2 \mathrm{~km} \mathrm{msl}),(2)$ the AEJ (4-6 km msl) and (3) the intermediate layer $(2-4 \mathrm{~km} \mathrm{msl})$ are observed. Of particular interest to this study are the low level winds to the north and to the south of the ITD. In the low levels, i.e., below $2 \mathrm{~km} \mathrm{msl,}$ the bias between the WIND observations and the simulation is relatively small on average south of the ITD $\left(+0.24 \mathrm{~m} \mathrm{~s}^{-1}\right.$ and $-8.3^{\circ}$, see Table 1 ), meaning that the simulated winds are slightly weaker and exhibit a slight clockwise turning of the wind vector with respect to the observations. North of the ITD, the simulated winds are on the contrary substantially stronger and exhibit a slight anticlockwise turning of the wind vector with respect to the observations.

[30] The largest wind speed bias is seen to be associated with the AEJ north of $18.5^{\circ} \mathrm{N}$, meaning the speed of the AEJ is largely underestimated, while its direction is well reproduced. This is not so much the case south of $18.5^{\circ} \mathrm{N}$. In the intermediate layer, wind speed and direction are fairly well reproduced in the model south of $18.5^{\circ} \mathrm{N}$, while to the north the model tends to overestimate the wind speed while making it slightly more northerly with respect to the observations.

[31] Figure 7a shows the vertical structure of the total dust concentration field simulated by Meso-NH along the aircraft flight track at 0600 UTC on 7 July 2006. Large dust concentrations $\left(>1000 \mu \mathrm{g} \mathrm{m}^{-3}\right)$ are obtained above the surface just south of the ITD (at $18.5^{\circ} \mathrm{N}$ ) in connection with the strong near-surface winds as detailed by $\mathrm{Bou}$ Karam et al. [2008]. This is in good agreement with the large lidar reflectivity values (acquired with LEANDRE 2, Figure $7 \mathrm{~b}$ ) around $18.5^{\circ} \mathrm{N}$ which indicate large aerosol concentrations [see Bou Karam et al., 2008]. Important dust concentrations (between 300 and $1000 \mu \mathrm{g} \mathrm{m}^{-3}$ ) are also simulated along the monsoon-harmattan interface (delineated by the isotach zero of the simulated wind transverse to the cross section). This is also consistent with the LEANDREderived reflectivity field (Figure $7 b$ ) and is related to the transport of the dust lifted at the leading edge of the monsoon flow by circulation in the head of the "monsoon density current". Away from the leading edge, some of the mobilized dust was observed to mix across the monsoonharmattan interface, due to the existence of mechanical shear above the monsoon layer (around $17^{\circ} \mathrm{N}$ ), and to become available for long-range transport by the harmattan [Bou Karam et al., 2008]. The lidar data shows a second low-level dust maximum at $17^{\circ} \mathrm{N}$, south of the ITD (Figure 7b). This feature has been reported by Bou Karam et al. [2008] to be associated with the leading edge of a cold pool outflow from a mesoscale convective system over Niamey. The model does not show this second maximum in dust concentration, as deep convection is not activated in the simulation.

[32] The model and observations also both show a local maximum in dust at around $18.5^{\circ} \mathrm{N}$ at a height of $3 \mathrm{~km} \mathrm{msl}$. This feature corresponds to dust uplifted into the Saharan air layer and advected over the monsoon with the harmattan, leading to high Ozone Monitoring Instrument aerosol index values from elevated dust [e.g., Knippertz, 2008; Cuesta et al., 2009].

[33] The simulated turbulent kinetic energy field along the cross section (Figure 7c) is coherent with the observational picture and shows the presence of a core of high values along the monsoon-harmattan interface around $17^{\circ} \mathrm{N}$. Large turbulent kinetic energy values are also seen near the surface and further north along the monsoon-harmattan interface (closer to the leading edge of the monsoon), as well as associated with the African easterly jet around $19^{\circ} \mathrm{N}$. North of the ITD, large dust concentrations $(>1000 \mu \mathrm{g}$ $\mathrm{m}^{-3}$ ) are simulated near the surface, in connection with the strong low-level winds (Figure 5c). LEANDRE-derived reflectivity does not suggest the presence of dust loads as large as those observed to the south, in spite of the fact that the area is a known dust source, being located in the vicinity of mountain foothills where fluvial sediment provides fine material for deflation [e.g., Schepanski et al., 2007]. The fact that the simulated near-surface winds are greater than the observed ones north of the ITD is consistent with the fact that the model is mobilizing too much dust in this region with respect to LEANDRE 2 observations. Another possible explanation could be that the source north of $19^{\circ} \mathrm{N}$ was limited in its supply of erodible sediments and that deflatable sediments are no longer available to be mobi- 


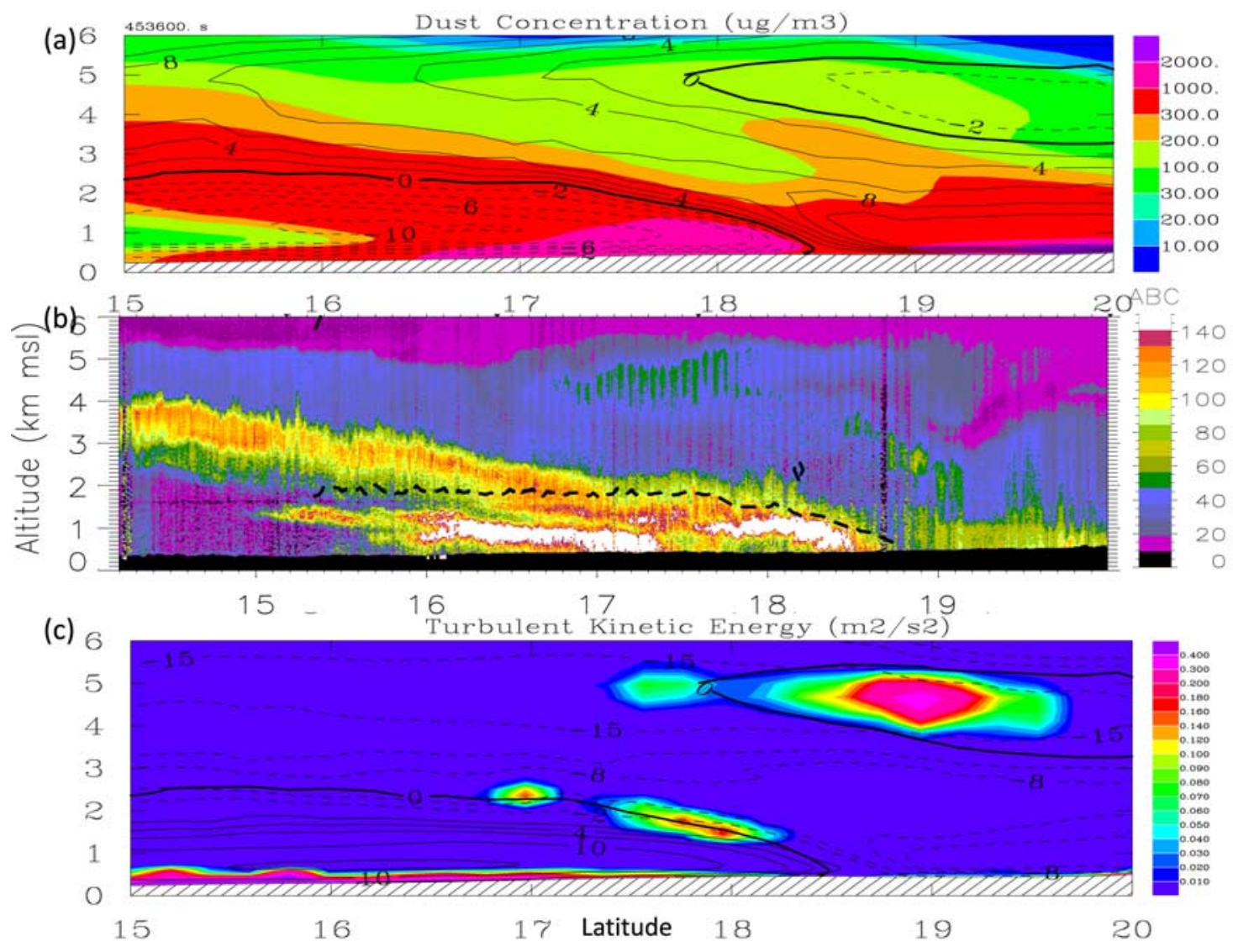

Figure 7. (a) Cross section of model-derived total dust concentration along the aircraft transect on 7 July at 0600 UTC. The thick solid line indicates the isotach zero of wind transverse to the cross section. Wind speed transverse to the cross section is contoured every $2 \mathrm{~m} \mathrm{~s}^{-1}$, with thin dashed lines indicating winds toward the reader and thin solid lines indicating winds away from the reader. (b) LEANDRE-2 derived atmospheric reflectivity at $730 \mathrm{~nm}$ obtained on 7 July 2006 along the aircraft transect between 0602 and 0658 UTC. The dashed black line represents the isotach zero of wind transverse to the cross section derived from WIND. (c) Same as Figure 7a, but for turbulent kinetic energy.

lized, while in the simulation the supply is unlimited (by construction). Another explanation could be the fact that the soil type in this area is very variable and this variability is not well represented in the model, so the model will not be able to reproduce the same dust emission along the precise location of the flight path. Also, some other discrepancies in the parameterization of the land surface in the model could lead to this difference.

[34] In summary, comparison with airborne lidar observations acquired on 7 July 2006 demonstrates that the model is able to reproduce the complex vertical structure of the dynamics and aerosol field associated with the monsoon-harmattan interface. Evaluation against surface observations in Niamey between 2 and 12 July period indicates that the near surface thermodynamic characteristics of the monsoon to the south of the ITD are realistically reproduced over the period of the simulation. The comparison with observations suggests that the model can be used reliably to analyze and quantify the dust emissions associated with the strong near-surface monsoonal winds blowing over the Sahelian dust sources during the period of interest. The agreement with the AOD observations in Banizoumbou suggests that the dust loads transported to the south from the
ITD region are reasonably well replicated, particularly from 6 July onward.

\section{Dust Loads Over the Central Sahel and the Central Southern Sahara}

\subsection{Total Dust Loads}

[35] The total dust load over the domain was computed from both model-derived and MODIS AODs, using the relationship proposed by Koren et al. [2006], and updated by Todd et al. [2007]:

$$
\mathrm{M}_{0}=\mathrm{A} \times \mathrm{F} \times \sigma,
$$

where $\mathrm{A}$ is the model domain area, $\sigma$ is the domain area average mean dust AOD and $\mathrm{F}$ is a coefficient set to $1.9 \mu \mathrm{g}$ $\mathrm{m}^{-2}$ [Todd et al., 2007]. Dust loads computed using equation (1) are shown in Figure 8. Observed dust loads are relatively constant during the period, around $3 \mathrm{Tg}$. The dust load derived from MODIS AODs is found to be larger than the modeled counterparts, except on 5, 7 and 8 July 2006. Assuming that emissions in the model are accurate, this implies that on these days the contribution of cold pools and long-range transport to the dust load in the domain may 


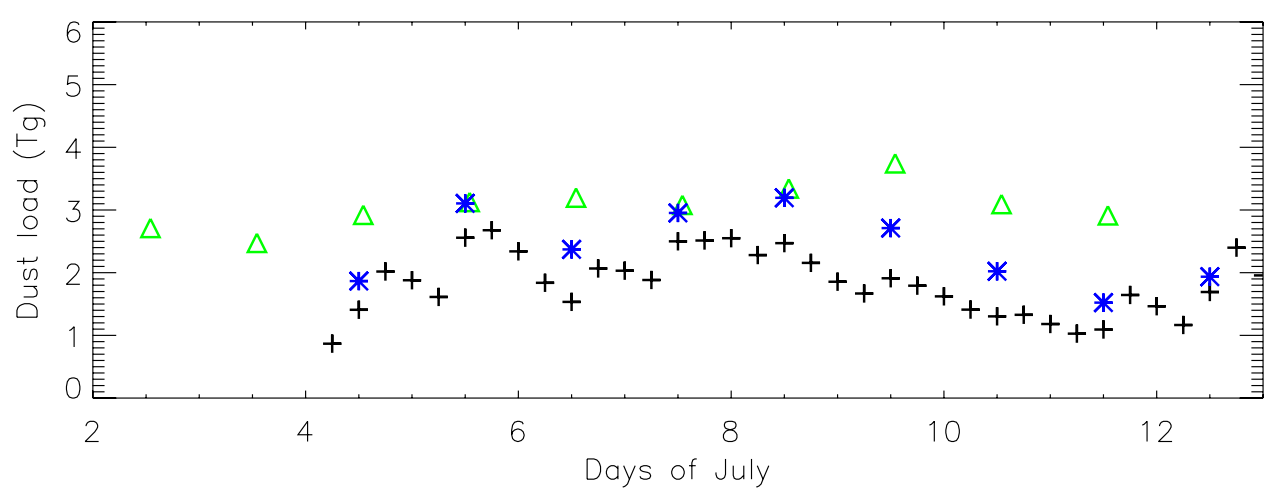

Figure 8. Temporal evolution of the dust load computed from model-derived total dust concentrations using equation (2) between the ground and $2000 \mathrm{~m}$ agl (crosses) from model-derived AODs using equation (1) (blue asterisks) and from MODIS-derived AODs using equation (1) (green triangles).

have been negligible, and that the total dust load was dominated by dust mobilized at the ITD. For the other days, the observed total dust load is larger that the modeled counterpart by a factor of approximately 1.33 . There again, assuming that emissions in the model are accurate, the difference may be due to long range transport of dust emitted in remote Saharan sources to the north, to the west and to the east of the domain, as well as dust mobilization by cold pools to the south. However, one should be cautious this could also be related to uncertainties in the properties of the dust in the model such as mineralogy, size distribution, and shape of the dust particles. Alternatively, model emissions may be too great (as discussed in section 4.3 above), especially to the north of the ITD, and that contribution from transport could be larger than inferred from the comparison between observed and modeled AODs.

\subsection{Dust Loads Associated With Emissions on Both Sides of the ITD}

[36] The model-derived dust load associated with nearsurface winds is estimated as the vertical integration of dust concentration in the lowest layers located between the surface and $2 \mathrm{~km}$ agl. The height of the upper boundary was imposed by the depth of the monsoon flow observed and simulated a few hundreds of kilometers south of the ITD (Figures 5 and 6). The temporal evolution of the modelderived dust load, averaged over the simulation domain, is shown in Figure 8. The dust loads are obtained every 6 hours from the dust concentration fields associated with the emission both to the north and to the south of the ITD, as:

$$
\mathrm{M}_{\mathrm{S}}=\mathrm{A} \times \Sigma_{\mathrm{k}} \mathrm{C}_{\mathrm{k}} \times \Delta \mathrm{z}_{\mathrm{k}}
$$

where $\mathrm{A}$ is the model domain area, $\mathrm{C}_{\mathrm{k}}$ is the domain area average mean dust concentration at level $\mathrm{k}$ and $\Delta \mathrm{z}_{\mathrm{k}}$ is the depth of the layer comprised between levels $\mathrm{k}-1$ and $\mathrm{k}$. The dust load is simulated to increase between 4 and 8 July, and decrease afterward. The evolution of the dust load between 0 and $2 \mathrm{~km}$ agl retrieved from equation (2) shows some consistency with the dust load derived from modeled AODs using equation (1) (Pearson linear correlation coefficient of 0.65 ).

[37] During the 2-12 July period, the amount of dust mobilized within the domain is seen to increase from mean daily values of $1.8 \mathrm{Tg}$ on 4 July to $\sim 2.5 \mathrm{Tg}$ on 5,7 and 8 July, and to decrease from then on.

\subsection{Dust Loads Associated With Emissions at the Leading Edge of the Monsoon}

[38] The temporal evolution of the dust load below $2 \mathrm{~km}$ agl south of the ITD is shown in Figure 9a. Dust load increases from 4-8 July, and decreases afterward, in connection with the near surface wind speeds. The temporal evolution of the dust load below $2 \mathrm{~km}$ agl correlates well (linear Pearson correlation coefficient of 0.7 ) with the dust load in the lowest model layer (between model 30 and $60 \mathrm{~m}$ agl, respectively, Figure 9b). Interestingly, peak dust loads between 30 and $60 \mathrm{~m}$ agl are observed at 0000 UTC on 5, 7 and 8 July 2006.

[39] On 5 July the daily mean value of dust load in the monsoon layer south of the ITD was about $0.5 \mathrm{Tg}$ and increased to $0.8 \mathrm{Tg}$ on 7 and 8 July. Mean daily values between 9 and 11 July were on the order of $0.5 \mathrm{Tg}$.

[40] Assuming that emissions in the model are accurate, it appears that the dust load associated with the strong winds south of the ITD accounts for approximately one third (1/3) of the total load mobilized in the ITD region over the entire domain on a given day. However, as discussed in section 4.3 above, the simulated harmattan depth and the near-surface wind speed were found to be larger than their observed counterparts to the north of the ITD. The modelled harmattan dust layer is approximately 2 times deeper and the harmattan winds stronger by a factor of 1.15 (at most) than observed (Figure 7 and Table 1). So harmattan emissions could be out by a factor of $2-2.3$ in this region, meaning the fraction of dust emitted south of the ITD could be underestimated. If too much harmattan dust is being emitted relative to the monsoon, then the fraction of dust in the domain that is from the monsoon dynamics should actually be greater than $1 / 3$, and could reach $2 / 3$ in some instance, depending on the fractional area of the domain covered by the harmattan in the simulation.

\subsection{Discussion}

[41] In the present case, the daily average of dust load over the entire domain associated with emissions on both sides of the ITD was found to be on the order of $2.5 \mathrm{Tg}$ i.e., close to those derived downstream of the Bodélé depression (2.7 Tg) [e.g., Todd et al., 2008b], while the daily average of 

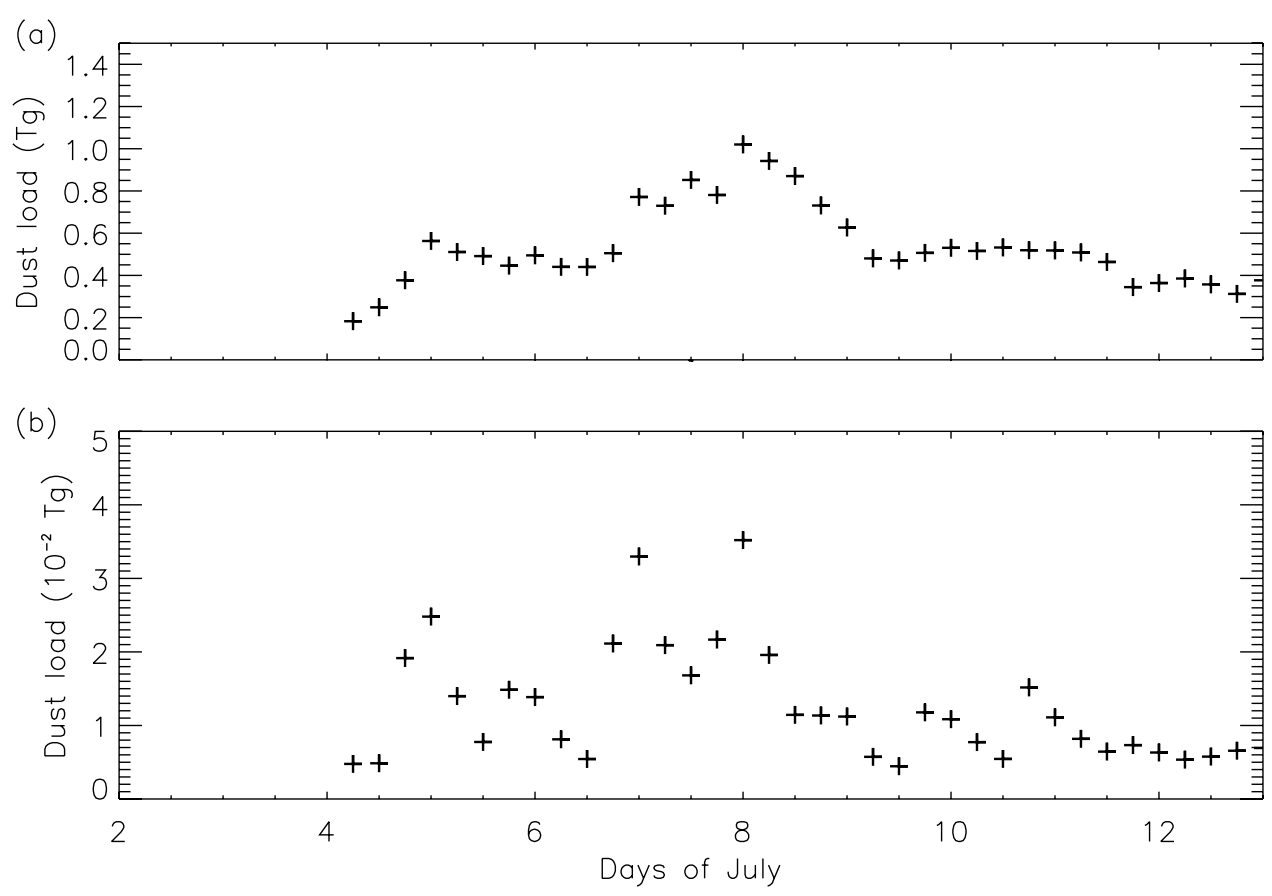

Figure 9. (a) Dust load south of the ITD computed from model-derived total dust concentrations using equation (2) between the ground and $2000 \mathrm{~m}$. (b) Same as Figure 9a, but computed between the ground and $30 \mathrm{~m}$.

dust load associated with emissions at the leading edge of the monsoon flow was estimated to range between 0.5 and $0.8 \mathrm{Tg}$. This suggests that the mean modeled dust load related to the mechanisms highlighted by Bou Karam et al. [2008] is comparable with the mean winter dust emissions from the Bodélé in one day $(0.77 \mathrm{Tg}$, estimated by Koren et al. [2006] using equation (2) with a coefficient $F$ set to $2.7 \mu \mathrm{g} \mathrm{m}^{-2}$ and using AODs derived from the Multiangle Imaging SpectroRadiometer (MISR) instrument). This study also suggests that the dust emitted north of the ITD is also significant (and likely larger than to the south).

[42] Given the model domain size, it is worth noting that not all sources spreading across the Sahel are accounted for in the simulation [e.g., Engelstaedter et al., 2006], and so we only provide a lower bound for the dust load associated with emission linked to strong surface winds on both sides of the ITD across Sahel (note that our domain does not include the Bodélé Depression).

[43] Furthermore, because the ITD is positioned over the Sahel for nearly 2 months during the Spring/Summer, we may realistically think that dust emissions occurring on both sides of the ITD while it lies above the dust hot spots may contribute significantly to the annual observed dust load over West and North Africa. Dust mobilization associated with strong winds on both sides of the ITD need to be well represented in the regional models.

\section{Summary and Conclusions}

[44] A three-dimensional mesoscale numerical simulation has been performed using Meso-NH to investigate the dust emissions over Sahel associated with strong near-surface winds in the region of the West African ITD during the summer, when the ITD is located over Niger and Mali around $18^{\circ} \mathrm{N}$. The study focuses on the period from 2 to 12 July 2006, in the framework of the AMMA Special Observing Period $2 \mathrm{a} 1$.

[45] The simulation was designed to reproduce only dust mobilization associated with strong near-surface winds. Deep convection is not activated in the simulation, and hence, dust mobilization associated with mesoscale convective systems cold pools is not modeled. Furthermore, the initial and lateral boundary conditions do not include information on the dust aerosol distribution at the regional scale, meaning that the model does not account for dust mobilized outside of the simulation domain.

[46] The study leads to the following conclusions:

[47] 1. The comparison with observations suggests that the model can be used reliably to analyze and quantify the dust emissions associated with the strong near-surface winds blowing over the Sahelian dust sources during the period of interest. In spite of the limited data set we believe that the model is able to reproduce the aerosol field at the ITD in general. In principle, a model validation exercise would require a long statistical basis (including simulations and observations) to assess whether the model realistically reproduces the aerosol field and the dynamics at the ITD. However, in the region of interest (the Sahel), given the fact that there is very few observations available, this "principle" is difficult to apply. Over the Sahel, the main sources of dynamics and thermodynamics observations are essentially ground based: surface stations (generally synoptic station providing 3-h data) which are not so numerous in the northern Sahel or sounding stations (synoptic as well, 2 soundings per day at most) which are really scarce. This is not much to validate a simulation from a dynamics point of view, even for a long simulation. Furthermore, concerning the aerosol data, the few AERONET stations and the space-borne products 
only provide vertically integrated fields that cannot be used to assess (even indirectly) the performance of model in terms of dynamics. This is why we consider the airborne lidar data (both dynamics and aerosol) to be extremely valuable in this particular case as they provide two-dimensional high resolution wind and aerosol field that can be compared with the model simulations. Even though the availability of such data is very limited (mostly during the AMMA Special Observing Period), we feel they can be used to assess the performance of the model even if it is only along a cross section. Such data provides much more insight into the processes of interest to this study than a surface station or a sounding station would.

[48] 2. The daily mean values of dust load related to the strong winds on both side of the ITD, as estimated from the simulation within the model domain $\left(2^{\circ} \mathrm{W}-16^{\circ} \mathrm{E}, 12-\right.$ $28^{\circ} \mathrm{N}$ ), are in excess of $2 \mathrm{Tg}$ on some of the days of the $2-12$ July 2006 period. In the present case, assuming that emissions in the model are accurate, the dust load associated with the strong winds south of the ITD accounts for approximately one third (1/3) of the total load mobilized in the ITD region over the entire domain on a given day. However, because the simulated harmattan depth and the near-surface wind speed were found to be larger than their observed counterparts to the north of the ITD, the fraction of dust in the domain that is associated with the monsoon dynamics could reach $2 / 3$ in some instance, depending on the fractional area of the domain covered by the harmattan in the simulation. Alternatively, model emissions may be underestimated due to the fact that the model does not represent subgrid scale winds which may be important for dust uplift [e.g., Marsham et al., 2008]. In this case the contributions from cold pools and transport could be larger than estimated and discussed from the comparison between observed and modeled AODs.

[49] 3. The dust load south of the ITD is simulated to range between 0.5 and $0.8 \mathrm{Tg}$ on average. This indicates that the mean daily dust load estimated in the ITD region is comparable with the winter dust emissions from the Bodélé depression in one day. In this study, the objective is not to assess an undisputable value of the dust emissions associated with the dynamics at the ITD, but rather based on a limited area simulation (with reliable dynamics) and for a given season of a given year, show that in some cases the mobilization at the ITD could be as important as that associated with often publicized events from the well known Bodélé region.

[50] Although no general conclusions can be drawn from just a 10-day period, the results presented here suggest that emissions driven by strong surface winds occurring on both sides of the ITD while it lies across the Sahel may contribute significantly to the total dust load over West and North Africa observed annually.

[51] Further investigation is needed to substantiate these findings, in particular performing longer simulations over the whole Sahel-Sahara in order to evaluate the contribution of the dust emissions in the ITD region to the total dust production during the summer dust season in West Africa.

[52] Acknowledgments. Based on a French initiative, AMMA was built by an international scientific group and is currently funded by a large number of agencies, especially from France, United Kingdom, United States, and Africa. It has been the beneficiary of a major financial contribution from the European Community's Sixth Framework Research Programme. Detailed information on scientific coordination and funding is available on the AMMA International Web site (http://www.ammainternational.org).

[53] We thank SAFIRE (Service des Avions Français Instrumentés pour la Recherche en Environnement, http://www.safire.fr), Institut Géographique National (IGN, http://www.ign.fr), and Division Technique of the Institut National des Sciences de 1'Univers (DT/INSU, www.dt.insu.cnrs.fr) for preparing and delivering the research aircraft (Falcon 20/F-GBTM) and the airborne instruments in a timely manner for the AMMA Special Observing Period. The deployment of the DLR Falcon aircraft during AMMA was partly funded by DLR, and we thank the professional support and operation staff of the aircraft by DLR flight facility. We also thank the AMMA Operation Center and their partners across West Africa for smoothing out many aspects of the airborne operations; D. Bruneau and P. Genau (LATMOS) and F. Blouzon, A. Abchiche, D. Chaize, and N. Amarouche (DT/INSU) for refitting and operating the LEANDRE 2 system in the F/F20; O. Reitebuch, P. Drobinski, P. Delville, M. L. Denneulin, B. Romand, E. Nagel, J. P. Aubagnac, and F. Lavie for the preparation, deployment, and operation of the WIND during AMMA, as well as the processing and analysis of the data; Alf Grini and Juan Escobar for their help and advice on the modeling issues; and two anonymous referees for their comments that improved the paper.

\section{References}

Alfaro, S. C., and L. Gomes (2001), Modelling mineral aerosol production by wind erosion: Emission intensities and aerosol size distributions in source areas, J. Geophys. Res., 106(D16), 18,075-18,084.

Barthe, C., G. Molinié, and J.-P. Pinty (2005), Description and first results of an explicit electrical scheme in a $3 \mathrm{~d}$ cloud resolving model, Atmos. Res., 76(1-4), 95-113.

Bechtold, P., E. Bazile, F. Guichard, P. Mascart, and E. Richard (2001), A mass-flux convection scheme for regional and global models, $Q$. J. R. Meteorol. Soc., 127, 869-886.

Bougeault, P., and P. Lacarrère (1989), Parameterization of orographyinduced turbulence in a Mesobeta-scale model, Mon. Weather Rev., $117(8), 1872-1890$

Bou Karam, D., C. Flamant, P. Knippertz, O. Reitebuch, P. Pelon, M. Chong, and A. Dabas (2008), Dust emissions over the Sahel associated with the West African Monsoon inter-tropical discontinuity region: A representative case study, Q. J. R. Meteorol. Soc., 134, $621-634$.

Bou Karam, D., C. Flamant, P. Tulet, M. C. Todd, J. Pelon, and E. Williams (2009), Dry cyclogenesis and dust mobilization in the Inter Tropical Discontinuity of the West African Monsoon: A case study, J. Geophys. Res., 114, D05115, doi:10.1029/2008JD010952.

Bruneau, D., P. Quaglia, C. Flamant, M. Meissonnier, and J. Pelon (2001), The airborne lidar LEANDRE II for water-vapor profiling in the troposphere: I. System description., Appl. Opt., 40, 3450-3475.

Buckle, C. (1996), Weather and Climate in Africa, Addison-Wesley Longman Ltd., Harlow, U. K.

Chaboureau, J.-P., P. Tulet, and C. Mari (2007), Diurnal cycle of dust and cirrus over West Africa as seen from Meteosat Second Generation satellite and a regional forecast model, Geophys. Res. Lett., 34, L02822, doi:10.1029/2006GL027771

Cohard, J.-M., and J.-P. Pinty (2000), A comprehensive two-moment warm microphysical bulk scheme: II. 2d experiments with non hydrostatic model, Q. J. R. Meteorol. Soc., 126, 1843-1859.

Cuesta, J., J. Marsham, D. Parker, and C. Flamant (2009), Dynamical mechanisms controlling the vertical redistribution of dust and the thermodynamic structure of the West Saharan Atmospheric Boundary Layer during Summer, Atmos. Sci. Lett., 10, 34-42.

Crumeyrolle, S., L. Gomes, P. Tulet, A. Matsuki, A. Schwarzenboeck, and K. Crahan (2008), Increase of the aerosol hygroscopicity by aqueous mixing in a mesoscale convective system: A case study from the AMMA campaign, Atmos. Chem. Phys., 8, 6907-6924.

Engelstaedter, S., and R. Washington (2007), Atmospheric controls on the annual cycle of North African dust, J. Geophys. Res., 112, D03103, doi:10.1029/2006JD007195.

Engelstaedter, S., I. Tegen, and R. Washington (2006), North African dust emissions and transport, Earth-Sci. Rev., 79, 73-100.

Flamant, C., J.-P. Chaboureau, D. J. P. Parker, C. M. Taylor, J.-P. Cammas, O. Bock, F. Timouk, and J. Pelon (2007), Airborne observations of the impact of a convective system on the planetary boundary layer thermodynamics and aerosol distribution in the inter-tropical discontinuity region of the West African Monsoon, $Q . J$. R. Meteorol. Soc., 133, 1175-1189.

Forster, P., et al. (2007), Changes in atmospheric constituents and in radiative forcing, in Climate Change 2007: The Physical Science Basis. 
Contribution of Working Group I to the Fourth Assessment Report of the Intergovernmental Panel on Climate Change, edited by S. Solomon, et al., Cambridge Univ. Press, Cambridge, U. K.

Grini, A., P. Tulet, and L. Gomes (2006), Dusty weather forecasts using the Meso-NH mesoscale atmospheric model, J. Geophys. Res., 111, D19205, doi:10.1029/2005JD007007.

Hamilton, R. A., and J. W. Archibald (1945), Meteorology of Nigeria and adjacent territory, Q. J. R. Meteorol. Soc., 71, 231-262.

Haywood, J., P. Francis, S. Osborne, M. Glew, N. Loeb, E. Highwood, D. Tanré, G. Myhre, P. Formenti, and E. Hirst (2003), Radiative properties and direct radiative effect of Saharan dust measured by the C-130 aircraft during SHADE: 1. Solar Spectrum, J. Geophys. Res., 108(D18), 8577, doi:10.1029/2002JD002687.

Jankowiak, I., and D. Tanré (1992), Satellite climatology of Saharan dust outbreaks: Method and preliminary results, J. Clim., 5, 646-656.

Koren, I., Y. J. Kaufman, R. Washington, M. C. Todd, Y. Rudich, J. V. Martins, and D. Rosenfeld (2006), The Bodélé Depression: A single spot in the Sahara that provides most of the mineral dust to the Amazon forest, Environ. Res. Lett., 1, 014005, doi:10.1088/1748-9326/1/1/014005.

Knippertz, P. (2008), Dust emissions in the West African heat trough - the role of the diurnal cycle and of extratropical disturbances, Meteorol. Z., 17(5), 001-011.

Knippertz, P., and A. H. Fink (2006), Synoptic and dynamic aspects of an extreme springtime Saharan dust outbreak, Q. J. R. Meteorol. Soc., 132, $1153-1177$.

Knippertz, P., C. Deutscher, K. Kandler, T. Müller, O. Schulz, and L. Schütz (2007), Dust mobilization due to density currents in the Atlas region: Observations from the SAMUM 2006 Field Campaign, J. Geophys. Res., 112, D21109, doi:10.1029/2007JD008774.

Lafore, J. P., et al. (1998), The Meso-NH atmospheric simulation system: Part I. Adiabatic formulation and control simulations, Ann. Geophys., 16, $90-109$.

Marsham, J. H., D. J. Parker, C. M. Grams, C. M. Taylor, and J. M. Haywood (2008), Uplift of Saharan dust south of the intertropical discontinuity, J. Geophys. Res., 113, D21102, doi:10.1029/2008JD009844.

Masson, V., J. Champeaux, F. Chauvin, C. Merguet, and R. Lacaze (2003), A global database of land surface parameters at $1-\mathrm{km}$ resolution $\mathrm{n}$ meteorological and climate models, J. Clim., 16, 1261-1282.

Noilhan, J., and J. F. Mahfouf (1996), The ISBA land surface parameterization scheme, Global Planet. Change, 13, 145-159.

Parker, D. J., R. R. Burton, A. Diongue-Niang, R. J. Ellis, M. Felton, C. M. Taylor, C. D. Thorncroft, P. Bessemoulin, and A. M. Tompkins (2005), The diurnal cycle of the west African monsoon circulation, Q. J. R. Meteorol. Soc., 131, 2839-2860.

Prospero, J. M., P. Ginoux, O. Torres, S. E. Nicholson, and T. E. Gill (2002), Environmental characterization of global sources of atmospheric soil dust identified with the Nimbus 7 Total Ozone Mapping Spectrometer (TOMS) absorbing aerosol product, Rev. Geophys., 40(1), 1002, doi:10.1029/2000RG000095.

Ramaswamy, V., O. Boucher, J. Haigh, D. Hauglustaine, J. M. Haywood, G. Myhre, T. Nakajima, and S. Solomon (2001), Climate Change 2000: The Science of Climate Change, IPCC, World Meteorological Organization, Cambridge Univ. Press, Cambridge, U. K.

Redelsperger, J.-L., C. D. Thorncroft, A. Diedhiou, T. Lebel, D. J. Parker, and J. Polcher (2006), African Monsoon Multidisciplinary Analysis: An International Research Project and Field Campaign, Bull. Am. Meteorol. Soc., 87, 1739-1746.

Reitebuch, O., C. Werner, I. Leike, P. Delville, P. H. Flamant, A. Cress, and D. Engelbart (2001), Experimental Validation of Wind Profiling Performed by the Airborne $10.6 \mu \mathrm{m}$-Heterodyne Doppler Lidar WIND, J. Atmos. Oceanic Technol., 18, 1331-1344.

Schepanski, K., I. Tegen, B. Laurent, B. Heinold, and A. Macke (2007), A new Saharan dust source activation frequency map derived from MSGSEVIRI IR-channels, Geophys. Res. Lett., 34, L18803, doi:10.1029/ 2007 GL030168.
Schepanski, K., I. Tegen, M. C. Todd, B. Heinold, G. Bonisch, B. Laurent, and A. Macke (2009), Meteorological processes forcing Saharan dust emission inferred from MSG-SEVIRI observations of sub-daily dust source activation, J. Geophys. Res., 114, D10201, doi:10.1029/2008JD010325.

Slingo, A., et al. (2008), Overview of observations from the RADAGAST experiment in Niamey, Niger: Meteorology and thermodynamic variables, J. Geophys. Res., 113, D00E01, doi:10.1029/2008JD009909.

Sterk, G. (2002), Causes, consequences and control of wind erosion in Sahelian Africa: A review, Land Degrad. \& Dev., 14, 95-108.

Suhre, K., et al. (1998), Physico-chemical modelling of the first aerosol characterization experiment (ace 1) lagrangian b: 1. A moving column approach, J. Geophys. Res., 103(D13), 16,433-16,455.

Tegen, I., P. Hollrig, M. Chin, I. Fung, D. Jacob, and J. Penner (1997), Contribution of different aerosol species to the global aerosol extinction optical thickness: Estimates from model results, J. Geophys. Res., 102(D20), 23,895-23,915.

Thorpe, A. J., and T. H. Guymer (1977), The nocturnal jet, $Q . J . R$. Metereol. Soc., 103, 633-653.

Todd, M. C., R. Washington, J. V. Martins, O. Dubovik, G. Lizcano, S. M'Bainayel, and S. Engelstaedter (2007), Mineral dust emission from the Bodélé Depression, northern Chad, during BoDEx 2005, J. Geophys. Res., 112, D06207, doi:10.1029/2006JD007170.

Todd, M. C., S. Raghavan, G. Lizcano, and P. Knippertz (2008a), Regional model simulations of the Bodélé low-level jet of northern Chad during the Bodélé Dust Experiment (BoDEx 2005), J. Clim., 21, 995-1012.

Todd, M. C., et al. (2008b), Quantifying uncertainty in estimates of mineral dust flux: An inter-comparison of model performance over the Bodélé Depression, Northern Chad, J. Geophys. Res., 113, D24107, doi:10.1029/ 2008JD010476.

Tulet, P., V. Crassier, F. Cousin, K. Suhre, and R. Rosset (2005), ORILAM, a three moment lognormal aerosol scheme for mesoscale atmospheric model. On-line coupling into the Meso-NH-C model and validation on the Escompte campaign, J. Geophys. Res., 110, D18201, doi:10.1029/ 2004JD009871.

Tulet, P., M. Mallet, V. Pont, J. Pelon, and A. Boone (2008), The 7-13 March 2006 dust storm over West Africa: Generation, transport and vertical stratification, J. Geophys. Res., 113, D00C08, 10.1029/ 2008JD009871.

Washington, R., and M. C. Todd (2005), Atmospheric controls on mineral dust emission from the Bodélé Depression, Chad: Intraseasonal to interannual variability and the role of the low level jet, Geophys. Res. Lett., 32, L17701, doi:10.1029/2005GL023597.

Werner, C., et al. (2001), WIND instrument, Opt. Eng., 40, 115-125.

Zender, C., H. Bian, and D. Newman (2003), The mineral dust entrainment and deposition model DEAD: Description and 1990s dust climatology, J. Geophys. Res., 108(D14), 4416, doi:10.1029/2002JD002775.

D. Bou Karam and C. Flamant, Institut Pierre et Simon Laplace, CNRS, Université Pierre et Marie Curie, Service d' Aéronomie, Tour 45/46, $3^{\circ}$ étage, boite 308, 4, Place Jussieu, F-75005 Paris, France. (diana@aero. jussieu.fr; cyf@aero.jussieu.fr)

J.-P. Chaboureau, Laboratoire d'Aerologie, Observatoire Midi-Pyrenees, University of Toulouse/CNRS, 14 avenue Belin, F-31400 Toulouse, France. (jean-pierre.chaboureau@aero.obs-mip.fr)

A. Dabas, Centre National de Recherche Meteorologique, GMEI/LISA, Météo-France, 42 avenue Gustave Coriolis, F-31057 Toulouse, France. (alain.dabas@meteo.fr)

M. C. Todd, Department of Geography, University College London, Pearson Building, Gower Street, London WC1E 6BT, UK. (m.todd@geog. ucl.ac.uk)

P. Tulet, Centre National de Recherche Meteorologique/Groupe d'etude de l'Atmosphere MEteorologique, Météo-France, 42 avenue Gustave Coriolis, F-31057 Toulouse, France. 